\title{
Wybrane aspekty zielonego budownictwa w Polsce w kontekście systemów certyfikacji budynków ekologicznych
}

\author{
Aleksandra Lewandowska ${ }^{*}$, Krzysztof Rogatka, Mirosław Wylon \\ Katedra Studiów Miejskich i Rozwoju Regionalnego, Wydział Nauk o Ziemi \\ Uniwersytet Mikołaja Kopernika w Toruniu, ul. Lwowska 1, 87-100 Toruń \\ *amal@umk.pl•ORCID 0000-0002-1694-5151
}

\begin{abstract}
Streszczenie
Celem pracy jest wyjaśnienie specyfiki i ocena zielonego budownictwa w Polsce w kontekście procesu certyfikacji budownictwa ekologicznego. Ponadto w opracowaniu podjęto próbę określenia czynników tak społecznych, jak i ekonomicznych, które przyczynią się do rozwoju tego typu budownictwa w Polsce. W pracy również omówiono zróżnicowanie przestrzenne w skali województw lokalizacji budynków posiadających certyfikat budownictwa ekologicznego, a także wskazano strukturę zielonego budownictwa w Polsce. W celu realizacji zamierzonych zadań badawczych posłużono się głównie danymi z Polskiego Stowarzyszenia Budownictwa Ekologicznego. W pracy wykazano wzrost liczby wydanych certyfikatów budownictwa ekologiczne, co świadczy o rozwoju tego typu budownictwa. Stwierdzono też znaczne zróżnicowanie przestrzenne zielonego budownictwa w skali kraju. Wykazano również, że zdecydowana większość budynków, które otrzymały certyfikat budownictwa ekologicznego jest zlokalizowana w dużych miastach w Polsce.
\end{abstract}

\section{Slowa kluczowe}

zielone budownictwo, budownictwo ekologiczne, ekologizacja, miasto, Polska

\section{Wprowadzenie}

„Zielone budownictwo" jest bez wątpienia zagadnieniem wielowymiarowym. Z jednej strony jest ściśle powiązane z ekologiczną płaszczyzną budownictwa, która przejawia się przede wszystkim w spełnianiu określonych kryteriów dotyczących dbałości o środowisko naturalne przy konstruowaniu lub też odnawianiu budynków. W tym sensie nawiązuje mocno do idei zrównoważonego budownictwa (John i in. 2005, Berardi 2013). Z drugiej strony akcentuje znaczenie terenów zieleni przy projektowaniu budynków wraz z wykorzystaniem, w jak największym stopniu, zieleni w otoczeniu zabudowy oraz we wnętrzach (np. wertykalne ściany z zieleni) (Szymańska i in. 2015, Lewandowska, Rogatka 2017). Z trzeciej zaś strony wpływa bezpośrednio na jakość życia mieszkańców i implikuje szereg korzyści społecznych dotyczących m.in. poprawy warunków zdrowotnych, komfortu użytkowania budynku, budowania wspólnoty, dla której ważne są te same idee środowiskowe, oraz zwiększania świadomości ekologicznej. Należy zatem przyjąć, że zielone budownictwo można 
analizować w trzech wymiarach: technologiczno-technicznym, środowiskowym i społecznym.

W literaturze można również spotkać się $\mathrm{z}$ terminem zrównoważone budownictwo jako synonimem zielonego budownictwa. Wyjaśniając znaczenie tych terminów, trzeba zauważyć, że w obu przypadkach jest to praktyka wykorzystywania procesów i tworzenia struktur, które są przyjazne dla środowiska i zasobooszczędne w całym cyklu życia budynku. „Zielone budynki” odnoszą się do struktur utworzonych z wykorzystaniem zasad i metodologii zrównoważonego budownictwa, których celem jest stworzenie energooszczędnych, zdrowych i produktywnych budynków (np. produkujących, ale zarazem oszczędzających energię elektryczną), które zmniejszają znacząco negatywny wpływ budynków zarówno na środowisko miejskie, jak i na środowisko w skali globalnej.

Historia zielonego budownictwa sięga znacznie dalej niż mogłoby się przypuszczać W trakcie rewolucji przemysłowej Henri Becquerel po raz pierwszy był świadkiem transformacji energii słonecznej w energię elektryczną, zwaną później jako energia fotowoltaiczna. Mniej więcej w tym czasie, tj. od końca 1800 r. do początku XX w., zbudowano wiele elektrowni słonecznych, które wykorzystały energię słoneczną do wytwarzania pary (Wilson 2006). Następnie, w latach 50. XX w., energia słoneczna była wykorzystywana na bardzo małą skalę, co otworzyło drogę do powstania dwadzieścia lat później paneli słonecznych. Podczas kryzysu energetycznego w latach 70. XX w. zielone budownictwo przeszło z fazy badań i projektów do urzeczywistnienia (Wilson 2006). Konstruktorzy i projektanci rozpoczęli poszukiwania sposobów zmniejszenia zależności budynków i domów od paliw kopalnych. W tym celu wykorzystywano w pierwszej kolejności panele słoneczne do stworzenia bardziej przyjaznych dla środowiska domów, choć początkowo tylko w niewielkiej liczbie ze względu na wysokie koszty budowy (Wilson 2006).
Książka Rachel Carson, Silent Spring, opublikowana w 1962 r., jest uważana za jedną z pierwszych prób opisania zrównoważonego rozwoju w kontekście zielonego budownictwa. Projektowanie „zielonych budynków" zostało intensyfikowane pod koniec lat 8o. ubiegłego wieku, kiedy zrównoważony rozwój został określony przez Światową Komisję ds. Środowiska i Rozwoju ONZ (Wei i in. 2015). Wypracowanie koncepcji zrównoważonego rozwoju miało stać się remedium na coraz to częściej pojawiające się problemy ekologiczne współczesnego świata. W związku z tym rozpoczęły się poszukiwania obszarów wdrożeniowych dla zrównoważonego rozwoju. Budownictwo z uwagi na swój relatywnie duży udział w degradacji środowiska jest odpowiednim sektorem do implementowania zasad zrównoważonego rozwoju.

Rozwój zielonego budownictwa jest zdeterminowany swoistego rodzaju transformacją na rynku budowlanym. W Polsce i Europie współcześnie mamy do czynienia z zintensyfikowanym wzrostem zysków z sektora budowlanego. Z danych GUS wynika, że w okresie styczeń-grudzień 2018 r. produkcja budowlano-montażowa w firmach zatrudniających powyżej dziewięciu osób była blisko o jedną czwartą wyższa w porównaniu $\mathrm{z}$ analogicznym okresem 2017 (GUS 2019). Ponadto obserwujemy, że w grudniu 2018 r. w stosunku do roku poprzedniego największy wzrost $(24,2 \%)$ produkcji budowlano-montażowej odnotowano w jednostkach, których podstawowym rodzajem działalności jest właśnie budowa budynków. Warto również wspomnieć, że wzrosty odnotowały także przedsiębiorstwa, których podstawowym rodzajem działalności jest budowa obiektów inżynierii lądowej i wodnej $(11,4 \%)$ oraz jednostki zajmujące się wykonywaniem robót specjalistycznych (o,6\%) (GUS 2019). Te czynniki wskazują, że budownictwo staje się ważną gałęzią gospodarki w Polsce, która dynamicznie się rozwija. Zwiększone zyski branży budowlanej zachęcają do inwestycji nie tylko w tradycyjne gałęzie budownictwa, lecz także te 
bardziej kosztochłonne, jednocześnie bardziej przyszłościowe i przyjazne środowisku. Przykładem tego jest zielone budownictwo (Ulubeyli, Kazanci 2018).

W celu osiągnięcia oczekiwanych rezultatów dotyczących wdrażania norm zrównoważonego rozwoju w budownictwie niezbędne jest, w czasie realizacji projektu, korzystanie z materiałów, metod i procedur operacyjnych, które minimalizują negatywne oddziaływane na środowisko w całej fazie projektu, od planowania i projektowania, po budowę i eksploatację (Hoffman, Henn 2008; Wu, Low 2010; Xia i in. 2013). W ciągu ostatnich dwóch dekad dla efektywnego zarządzania tymi działaniami kraje uprzemysłowione, które posiadają spójną i dobrze uregulowaną branżę budowlaną, opracowały własne wytyczne i systemy certyfikacji budynków w oparciu o ustalone standardy techniczne. Ponadto na świecie zaobserwowano zwiększony popyt na „zielone budynki”, zarówno ze strony osób prywatnych, jak i podmiotów gospodarczych. Wiele krajów i organizacji międzynarodowych zainicjowało systemy oceny zrównoważonego budownictwa. Obecnie istnieje wiele różnych systemów certyfikacyjnych wykorzystujących do oceny budynków ich efektywność środowiskową (Azhar i in. 2011). Certyfikacja umożliwiła większą kontrolę nad tym, co jest $\mathrm{w}$ istocie budownictwem ekologicznym, a co jest nim tylko z nazwy.

Celem opracowania jest wyjaśnienie i ocena zielonego budownictwa w Polsce w kontekście liczby wydanych certyfikatów budownictwa ekologicznego. Ponadto w pracy próbuje się odpowiedzieć na następujące pytania: czy można wskazać jak czynniki społeczne i ekonomiczne wpływają na rozwój zielonego budownictwa w Polsce; jakie są dominujące systemy certyfikacyjne budownictwa ekologicznego w Polsce; ile jest i gdzie są (miasto/wieś) zlokalizowane najczęściej budynki posiadające zielone certyfikaty; jakie jest zróżnicowanie przestrzenne inwestycji w zakresie zielonego budownictwa w Polsce; jaka jest struktura zielonego budownictwa w skali województw w Polsce.
W pracy wykorzystano dane z Polskiego Stowarzyszenia Budownictwa Ekologicznego (PSBE). Dotyczyły one liczby wydanych certyfikatów budownictwa ekologicznego (stan na 31 stycznia 2018 r.) sklasyfikowanych dla jednostek przestrzennych, takich jak województwo oraz gmina.

\section{Społeczne i ekonomiczne determinanty zielonego budownictwa}

Rozwój każdego typu budownictwa uzależniony jest od wielu czynników, zarówno tych o podłożu endogennym, jak i egzogennym, z czego większość z nich determinuje również zielone budownictwo. Do tych ostatnich, egzogennych, bez wątpienia należy zaliczyć uwarunkowania polityczno-prawne zielonego budownictwa. Wskazują one określone prawa i przepisy, które mogą wpływać na atmosferę inwestycyjnobiznesową w branży. Uwzględniają one przepisy prawne dotyczące planowania przestrzennego, warunków zabudowy, wykorzystywanych materiałów oraz zdrowia i bezpieczeństwa mieszkańców itp.

Unia Europejskiej uznała zielone budownictwo, koncentrujące się na ochronie środowiska naturalnego, dbałości o zdrowie i samopoczucie użytkowników budynków, za jeden ze swoich priorytetowych sektorów, co znalazło odzwierciedlenie w dokumencie Komisji Europejskiej (2019) W kierunku zrównoważonej Europy do 2030 roku. Komisja Europejska zaliczyła zielone budownictwo do tzw. sektorów wiodących, które mają bardzo duży potencjał innowacyjny, a także kluczowe znaczenie dla rozwoju gospodarki nowoczesnej Europy, co wynika z realizacji planu działania na rzecz gospodarki o obiegu zamkniętym (Komisja Europejska 2019a). W unijnym prawodawstwie można odnaleźć wiele dyrektyw i rozporządzeń, które odnoszą się do zielonego budownictwa, m.in. rozporządzenie w sprawie etykiet energetycznych produktów związanych $\mathrm{z}$ energią; rozporządzenie ustanawiające zharmonizowane warunki wprowadzania do obrotu wyrobów budowlanych (CPR); „Recast" dyrektywy w sprawie charakterystyki 
energetycznej budynków (EPBD); dyrektywa ustanawiająca ogólne zasady ustalania wymogów dotyczących ekoprojektu dla produktów związanych $\mathrm{z}$ energią (Mazur-Wierzbicka 2014). Ponadto wymienić można także dyrektywę w sprawie charakterystyki energetycznej budynków, dyrektywę w sprawie efektywności energetycznej oraz w sprawie promowania odnawialnych źródeł energii. Wszystkie one mają na celu stworzenie norm, na których opiera się rozwój zielonego budownictwa.

Warto również odnotować, że czynnik ekonomiczny w odniesieniu do zielonego budownictwa jest niezwykle istotny. Warunkuje on w dużej mierze decyzję dotyczącą rozpoczęcia inwestycji. Koszty zielonego budownictwa na etapie projektu i wykonania są zazwyczaj wyższe, aniżeli w przypadku tradycyjnego budownictwa (Nelson i in. 2010, Hwang, Ng 2013). Wiąże się to z wykorzystaniem innowacyjnych technologii, które częstokroć są droższe od swoich pierwotnych odpowiedników. Należy jednak zaznaczyć, że opłacalność projektów z zakresu budownictwa ekologicznego dotyczy niższych kosztów eksploatacji budynku wynikających z zastosowania efektywniejszych technologii pozwalających na uzyskiwanie znacznych oszczędności (Mazur-Wierzbicka 2014). Niższych kosztów eksploatacji oczekują przede wszystkim przyszli użytkownicy takich budynków, co też jest dla nich dużą zachętą przy dokonywaniu wyboru, na jaki typ budownictwa się zdecydować.

Wzrost w społeczeństwie popytu na zielone budownictwo związane jest ze wzrostem świadomości ekologicznej, który obserwujemy w ostatnim czasie. W Polsce edukacja ekologiczna zaczęła się kształtować w latach 80. i 9o. XX w., niemniej w tym okresie mieszkańcy Polski nie mieli dużej wiedzy na temat problemów środowiskowych i wpływu człowieka na środowisko. Dopiero w XXI w. można było zaobserwować w Polsce wzrost zainteresowania tematyką ekologiczną, a społeczeństwo zaczęło dostrzegać, że postępowanie wpływa na jakość środowiska (Kłos 2015). Społeczeństwo staje się coraz bardziej świadome problemów ekologicznych, dlatego też poszukuje nowych rozwiązań, które zapewnią zdrowe warunki życia i pracy.

W celu stworzenia zdrowego środowiska do życia dla mieszkańców należy utrzymać wysoką jakość środowiska wewnętrznego. Użytkownicy „zielonych budynków” są zadowoleni z komfortu cieplnego i jakości powietrza w tych domach. Jednakże badania Abbaszadeh i in. (2006) wskazują, że analizując średni poziom zadowolenia pod względem oświetlenia i jakości akustycznej w zielonym budownictwie, odnotowano, że był on porównywalny do średniej pochodzącej ze standardowego budownictwa. Widać zatem, że są to obszary, nad którymi należy jeszcze popracować.

W praktycznym wdrażaniu zielonego budownictwa do przestrzeni miejskiej czy też wiejskiej ważne jest współdziałanie w wielu obszarach, które zapewnią docelowo zrównoważony rozwój danego obszaru. Przy projektowaniu zielonych budynków uwage zwraca się zarówno na aspekty środowiskowe, jak i jakość powietrza, wody, czy też monitorowanie zanieczyszczeń, ale również aspekty społeczne, takie jak wprowadzenie udogodnień dla osób niepełnosprawnych.

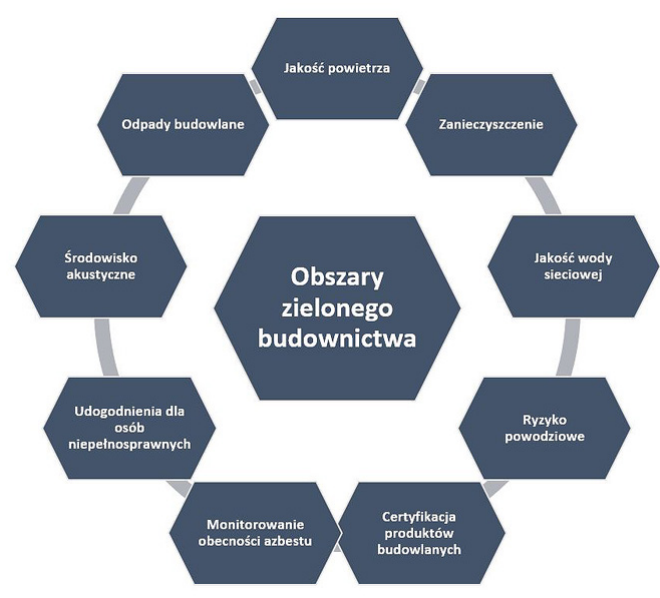

Ryc. 1. Obszary zielonego budownictwa Źródło: opracowanie własne na podstawie Paradysz (2012) 
Osiągnięcie „zielonych” standardów jest możliwe dzięki innowacjom technologicznym, a także dzięki używaniu wyłącznie certyfikowanych produktów budowlanych. Aktywność prośrodowiskowa jest jedną z popularniejszych i przyszłościowych działalności w gospodarce światowej i regionalnej, dlatego też obserwujemy coraz większą liczbę ekoinnowacji w budownictwie. Można wśród nich wymienić chociażby: „zielone” ściany i dachy, innowacyjne materiały i technologie budowane, płytki podłogowe produkujące energię, naturalne systemy wentylacyjne i grzewcze, systemy pozyskania energii z odnawialnych źródeł oraz ściany oddychające (Lewandowska 2015). Wszystkie te elementy podnoszą jakość życia mieszkańców, obniżając jednocześnie negatywny wpływ na środowisko.

\section{Rola systemów certyfikacyjnych budynków ekologicznych w rozwoju zielonego budownictwa}

W celu wdrażania zrównoważonego rozwoju w budownictwie należało w pierwszej kolejności wypracować konkretne narzędzia, które służyłyby ocenie budownictwa pod kątem spełniania norm budowlanych i wykorzystania proekologicznych rozwiązań. Na świecie istnieje wiele programów certyfikacyjnych. W tabeli 1 . zaprezentowano zestawienie wybranych z nich. Opierają się one na pomiarach, które pozwalają analitykom ocenić poziom, w jakim osiągane są cele zrównoważonego rozwoju budynków wskazanych przez właściciela i projektanta w dokumentacji techniczno-projektowej budynku. Pomiar wydajności wymaga istnienia dobrze zdefiniowanych kryteriów, które odnoszą się do konkretnych problemów związanych ze zrównoważonym rozwojem (Todd, Boecker 2008). Standardy, które są formułowane dla konkretnych systemów certyfikacyjnych, odgrywają ważną rolę przy ocenie budynków. Należy jednak zauważyć, że przyjmowane normy nie funkcjonują jako rozwiązania problemów, lecz jako wytyczne dla praktyków do opracowywania, jak te problemy rozwiązywać (Trinius, Sjoström
2007). Wielu autorów wskazuje, że standardy muszą jasno określać cele, ale również powinny posiadać kompleksowy zakres, elastyczny sposób radzenia sobie z kwestiami problemowymi, a także wymagają ciągłego doskonalenia (Lent, Walsh 2008; Komurlu i in. 2015).

W Stanach Zjednoczonych powstał system Leadership in Energy and Environmental Design (LEED), który jest obecnie najszerzej stosowaną metodą oceny efektywności środowiskowej budynku. LEED został opracowany przez US Green Building Council (USGBC) w 1998 r., aby zapewnić właścicielom budynków i operatorom zwięzłe ramy dla identyfikacji oraz wdrażania praktycznych i wymiernych rozwiązań w zakresie projektowania, budowy, eksploatacji i konserwacji zielonych budynków (Azhar i in. 2011). System ten funkcjonuje w 167 krajach (USGBC 2019). BREEAM (Building Research Establishment Environmental Assessment Method), jest drugim najczęściej stosowanym system oceniania zielonych budynków wykorzystywanym w 77 krajach (BREEAM 2019). Kolejnym przykładem jest niemiecki Deutsche Gesellschaft für Nachaltiges Bauen (DGNB), który pozwala na zastosowanie wytycznych umożliwiających budowanie nieruchomości w sposób przyjazny środowisku (DGNB 2019). $\mathrm{HQE}^{\mathrm{m}}$ (High Quality of Environment) jest z kolei przykładem etykiety (nie normy), która potwierdza, że inicjatywa właściciela projektu, mająca na celu osiągnięcie założeń dla zrównoważonego budynku lub obszaru, zakończyła się powodzeniem, dzięki czemu może być stosowana w różnych częściach świata (BeHQE 2019). Należy zatem zauważyć, że sektor budownictwa ekologicznego szybko się rozwija i jest rozpowszechniony na całym świecie. Wszystkie wymienione systemy certyfikacyjne honorują tylko wysokie standardy proekologiczne, a wśród nich stawiają przede wszystkim na: efektywną gospodarkę wodną, wysoką jakość i dbałość o zdrowie i życie mieszkańców, zrównoważoną lokalizację budynku oraz wysoką jakość środowiska wewnętrznego. 
Tabela 1. Systemy certyfikacyjne budownictwa ekologicznego

\begin{tabular}{lllll}
\hline \multicolumn{1}{c}{ BREEAM } & \multicolumn{1}{c}{ LEED } & \multicolumn{1}{c}{ DGNB } & HQE \\
\hline Kryteria & Zarządzanie obiektem & Zrównoważona lokalizacja & Ekologia & Eko-budowa \\
& Zdrowie i dobre & inwestycji & Ekonomia & Eko-zarządzanie \\
& samopoczucie & Efektywność gospodarki & Czynnik społeczno- & Komfort \\
& Energia & wodnej & kulturowy & Zdrowie \\
& Transport & Wykorzystanie energii i & Technologia i procesy & \\
& Woda & atmosfery & Lokalizacja & \\
& Materiały & Wykorzystanie materiałów i & & \\
& Odpady & zasobów & & \\
& Użytkowanie ziemi i & Jakość środowiska & & \\
& ekologia & wewnętrznego & & Nowy budynek \\
& Zanieczyszczenie & & & Istniejący budynek \\
& Innowacje & & Renowacja \\
Przeznaczenie & Nowy budynek & Nowy budynek; & Nowy budynek & \\
& Rozbudowa budynku & Rozbudowa budynku & Istniejący budynek & \\
& Istniejący budynek & Istniejący budynek & Renowacja & \\
& Renowacja budynku & Renowacja budynku & & Zadowalający \\
& Elewacja i wnętrze & Elewacja i wnętrze budynku & & Bardzo dobry \\
& budynku & & Doskonały \\
\hline Poziomy & Niesklasyfikowany & Certyfikowany & Brąz & Wyjątkowy \\
punktacji & Zadowalający & Srebro & Srebro & \\
& Dobry & Złoto & Złoto & \\
& Bardzo dobry & Platyna & & \\
& Doskonały & & & \\
& Wybitny & & & \\
\hline
\end{tabular}

Źródło: opracowanie własne na podstawie BEEAM 2019; USGBC 2019; DGNB 2019; IWBI 2019

Tabela 2. Liczba certyfikatów budownictwa ekologicznego w województwach w Polsce w 2018 r.

System certyfikacyjny

BREEAM LEED

\begin{tabular}{lrrrrrrrrrrrrrrr} 
Województwo & Razem & $\mathrm{A}$ & $\mathrm{B}$ & $\mathrm{C}$ & $\mathrm{D}$ & $\mathrm{E}$ & $\mathrm{F}$ & \multicolumn{1}{c}{ Razem } & $\mathrm{A}$ & $\mathrm{B}$ & $\mathrm{C}$ & $\mathrm{D}$ & $\mathrm{E}$ & $\mathrm{F}$ \\
\hline Kujawsko-pomorskie & 12 & 0 & 2 & 2 & 0 & 8 & 0 & 2 & 0 & 2 & 0 & 0 & 0 & 0 \\
Pomorskie & 22 & 1 & 0 & 11 & 0 & 10 & 0 & 7 & 1 & 0 & 6 & 0 & 0 & 0 \\
Warmińsko-mazurskie & 2 & 0 & 1 & 0 & 0 & 1 & 0 & 1 & 0 & 1 & 0 & 0 & 0 & 0 \\
Zachodniopomorskie & 10 & 0 & 3 & 5 & 0 & 2 & 0 & 2 & 0 & 0 & 2 & 0 & 0 & 0 \\
Lubuskie & 3 & 0 & 1 & 0 & 0 & 2 & 0 & 0 & 0 & 0 & 0 & 0 & 0 & 0 \\
kódzkie & 24 & 0 & 2 & 10 & 0 & 12 & 0 & 5 & 0 & 0 & 4 & 0 & 1 & 0 \\
Mazowieckie & 299 & 2 & 26 & 221 & 11 & 38 & 1 & 72 & 3 & 3 & 63 & 0 & 1 & 2 \\
Dolnośląskie & 32 & 0 & 8 & 15 & 0 & 9 & 0 & 29 & 0 & 4 & 25 & 0 & 0 & 0 \\
Śląskie & 46 & 0 & 16 & 8 & 0 & 22 & 0 & 6 & 0 & 2 & 4 & 0 & 0 & 0 \\
Opolskie & 4 & 0 & 0 & 0 & 0 & 4 & 0 & 1 & 1 & 0 & 0 & 0 & 0 & 0 \\
Małopolskie & 66 & 6 & 0 & 48 & 1 & 11 & 0 & 18 & 0 & 1 & 16 & 0 & 1 & 0 \\
Świętokrzyskie & 2 & 0 & 0 & 0 & 0 & 2 & 0 & 0 & 0 & 0 & 0 & 0 & 0 & 0 \\
Podlaskie & 5 & 0 & 1 & 0 & 0 & 4 & 0 & 0 & 0 & 0 & 0 & 0 & 0 & 0 \\
Lubelskie & 7 & 0 & 1 & 0 & 0 & 6 & 0 & 0 & 0 & 0 & 0 & 0 & 0 & 0 \\
Wielkopolskie & 36 & 0 & 6 & 11 & 0 & 19 & 0 & 11 & 0 & 1 & 10 & 0 & 0 & 0 \\
Podkarpackie & 1 & 0 & 0 & 0 & 0 & 1 & 0 & 8 & 0 & 4 & 4 & 0 & 0 & 0 \\
\hline & & & & & & & & & & & &
\end{tabular}

Objaśnienia: A - Hotel; B - obiekt przemysłowy; C - Biurowiec; D - Bloki mieszkalne; E - Obiekty handlowe, F Szkoły. Źródło: opracowanie własne na podstawie danych z PSBE (2019) 


\section{Charakterystyka zielonego budownictwa w świetle systemów certyfikacyjnych}

W Polsce funkcjonuje pięć systemów certyfikacyjnych budownictwa ekologicznego, tj. BREEAM, LEED, HQE, DGNB oraz WELL. Pierwsze cztery zostały scharakteryzowane powyżej. System WELL jest najmłodszy, ponieważ w 2004 r. został wydany pierwszy certyfikat. Z roku na rok zyskuje on na popularności i jest obecny już w 32 krajach (IWBI 2019). Pierwszy certyfikat budownictwa ekologicznego w Polsce został wydany w styczniu 2010 r., pół roku później inny obiekt otrzymał certyfikację BREEAM. Od tego momentu obserwujemy systematyczny wzrost zarówno liczby budynków certyfikowanych, jak i powierzchni oddanej do użytku, która spełnia wymogi certyfikacyjne. Należy jednak zaznaczyć, że liczba wydanych certyfikatów ekologicznych nie pokrywa się z liczbą budynków certyfikowanych. Jest to związane z faktem, iż w ostatnich latach powstaje coraz więcej obiektów kompleksowych, gdzie jeden certyfikat obejmował kilka budynków.

Na koniec 2018 r. przyznano w Polsce 745 certyfikatów, z tego $571 \mathrm{w}$ systemie BREEAM, 161 - LEED, 5 - HQE oraz po 4 w systemach DGNB i WEEL. Warto w tym

(A)

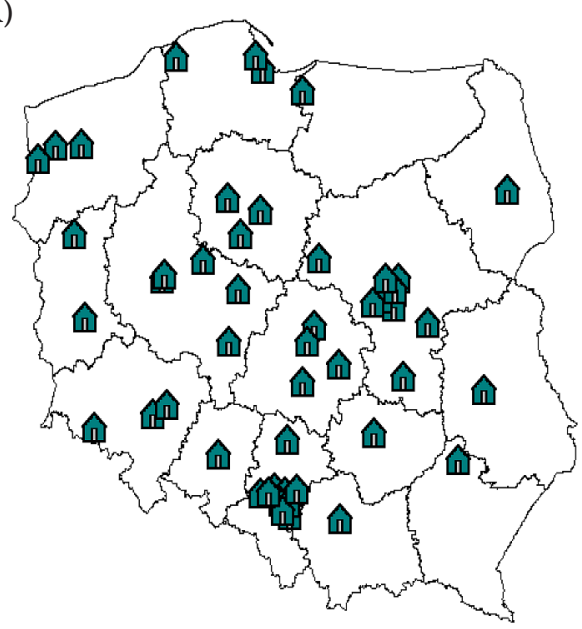

miejscu podkreślić, że jest to prawie dwukrotny wzrost w porównaniu do roku 2016. Świadczy to o bardzo dynamicznym rozwoju budownictwa ekologicznego w ostatnich latach.

Trzeba zaznaczyć, że ponad 98\% wydanych w Polsce certyfikatów przyznano w dwóch systemach certyfikacyjnych, dlatego też w dalszej analizie będą brane pod uwagę tylko certyfikaty BREEAM i LEED. Omawiając strukturę budynków pod kątem uzyskanych certyfikatów ekologicznych według rodzaju użytkowania powierzchni, należy zauważyć, że w większości są to budynki biurowe. Przykładami takich budynków są: Andersia Tower-Office w Poznaniu, Arkońska Business Park Faza I w Gdańsku, K1 w Krakowie oraz Horizon Plaza w Warszawie. W przypadku certyfikacji BEEAM jest to $58 \%$, a w LLED $-83 \%$. W strukturze certyfikatów BREEAM ponad $26 \%$ stanowią obiekty handlowe, $12 \%$ budynki przemysłowe, po $2 \%$ obiekty hotelowe i mieszkaniowe, tylko 1 szkoła uzyskała certyfikat w tym systemie (por. tab. 2). Struktura certyfikatów LEED jest mniej zróżnicowana, oprócz dominujących certyfikatów dla budynków biurowych, 11\% stanowią certyfikaty dla obiektów przemysłowych, 3\% - hotelowych, $2 \%$ - handlowych oraz $1 \%$ - szkoły.

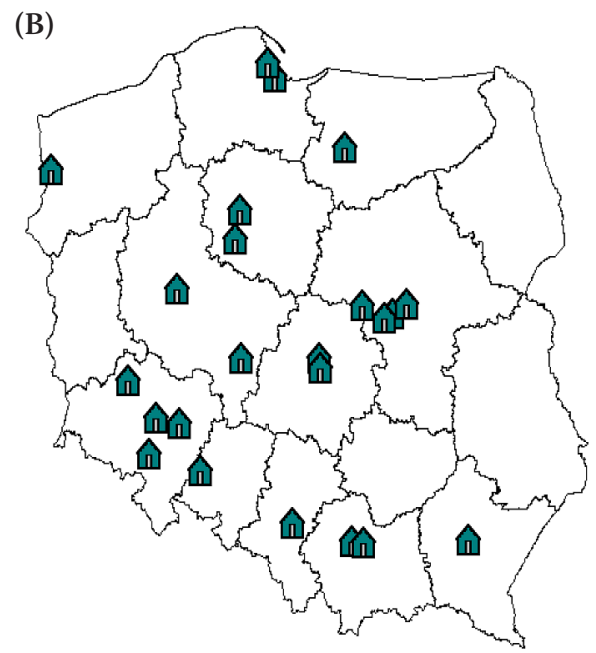

Ryc. 2. Lokalizacja budynków z certyfikatami BREEAM (A) i LEED (B) w 2018 r. Źródło: opracowanie własne na podstawie danych z PSBE (2019) 

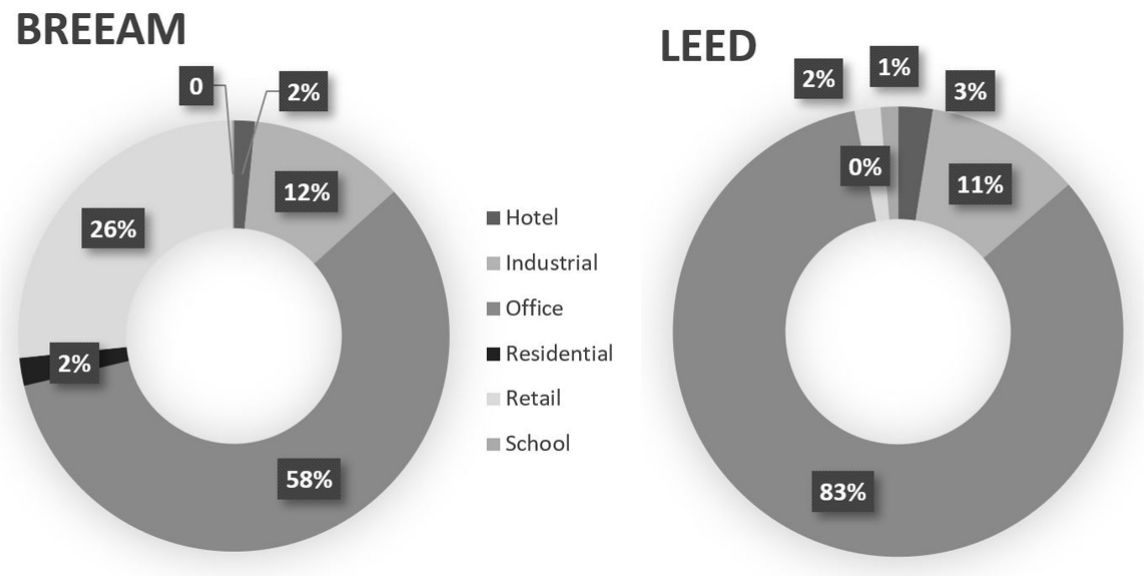

Ryc. 3. Struktura certyfikatów budownictwa ekologicznego według sytemu BREEAM i LEED w kontekście typu budynku

Źródło: opracowanie własne na podstawie danych z PSBE (2019)

Omawiając liczbę certyfikatów ekologicznych względem województw, odnotowano, że ponad $50 \% \mathrm{z}$ nich przyznano w województwie mazowieckim (tj. 371), z tego 90\% w samej tylko Warszawie. Na województwo małopolskie przypada $11 \%$ certyfikatów, $8 \%$ - dolnośląskie, $7 \%$ - śląskie i 6\% - wielkopolskie. Udział pozostałych województw w ogólnej liczbie certyfikatów budownictwa ekologicznego wyniósł poniżej $5 \%$. Co charakterystyczne, najmniej budynków certyfikowanych jest w województwach wschodnich. To wyraźne zróżnicowanie przestrzenne widoczne jest również na rycinie 1, gdzie dodatkowo podkreślenia wart jest fakt, że w województwach lubuskim i podlaskim nie przyznano żadnego certyfikatu LEED.

Analizując lokalizację budynków certyfikowanych, należy zauważyć, że w większości są one usytuowane w miastach. Tylko nieliczne certyfikaty ekologiczne dotyczą obiektów powstałych na terenie gmin wiejskich, przy czym należy zaznaczyć, że na obszarach podmiejskich, a także, iż większości są to budynki przemysłowe. Przykładami są: DB Schenker Terminal Olsztyn zlokalizowany w Stawigudzie, ProLogis Park Szczecin DC2 w Łozienicy, kompleks budynków Prologis Park Wrocław w Nowej Wsi Wrocławskiej. Najwięcej certyfikatów budownictwa ekologicznego, o czym już wspomniano, przyznano w Warszawie (334), następnie w Krakowie (83),Wrocławiu (44) oraz Poznaniu (31). Widać zatem, że budownictwo ekologiczne bardziej rozpowszechnia się w dużych miastach z uwagi na większy kapitał, którym dysponują inwestorzy, jak również ze względu na prestiż lokalizacji. Dysproporcje w zakresie lokalizacji tego typu obiektów w skali całej Polski są znaczne, co świadczy o tym, że tylko wyselekcjonowane projekty i obiekty moga ubiegać się o certyfikat budownictwa ekologicznego, które - jako innowacja - pojawia się najczęściej w przestrzeniach dużych miast w Polsce.

\section{Zakończenie}

W świetle przeprowadzonych badań wynika, że w ostatnich latach obserwujemy rozwój budownictwa ekologicznego w Polsce, czego potwierdzeniem jest liczba wydanych certyfikatów. Dominującymi na polskim rynku certyfikatami budownictwa ekologicznego są BREEAM i LEED. Najczęściej w strukturze budynków ekologicznych dominują biurowce, co jest potwierdzeniem ogólnoświatowej tendencji w tym zakresie. Decydującą kwestią wpływającą na zróżnicowanie przestrzenne lokalizacji zielonego budownictwa jest czynnik ekonomiczny, który 
skłania inwestorów i właścicieli budynków do wybierania dużych miast. W miastach zazwyczaj są umiejscowione siedziby dużych firm i korporacji, które docelowo mogą być odbiorcami i użytkownikami tego typu obiektów. Oprócz pobudek wizerunkowych i biznesowych, zielone budownictwo dostarcza argumentów o charakterze użytkowym. W obiektach tych panuje m.in. przyjazna akustyka i dobra jakość powietrza, co sprawia, że miło spędza się w nich czas.

Polskie społeczeństwo staje się coraz bardziej świadome ekologicznie i wymagające, dlatego należy przypuszczać, że w niedalekiej przyszłości zielone budownictwo będzie się dynamicznie rozwijać, a normy ustanowione w systemach certyfikacyjnych staną się standardem dla całej branży budowlanej.

\section{Podziękowania}

Artykuł został zrealizowany w ramach grantu nr 1187-G dla Młodych Naukowców Wydziału Nauk o Ziemi Uniwersytetu Mikołaja Kopernika w Toruniu.

\section{Bibliografia}

Abbaszadeh S., Zagreus L., Lehrer D., Huizenga C., 2006, Occupant satisfaction with indoor environmental quality in green buildings, Proceedings of Healthy Buildings, Lizbona, t. 3, 365-370.

Azhar S., Carlton W.A., Olsen D., Ahmad I., 2011, Building information modeling for sustainable design and LEED ${ }^{\circ}$ rating analysis, Automation in Construction, 20, 2, 217-224,

BeHQE, 2019, <https://www.behqe.com/cerway/ essentials $>$, dostęp 20.01.2019.

Berardi U., 2013, Clarifying the new interpretations of the concept of sustainable building, Sustainable Cities and Society, 8, 72-78.

Dyrektywa Parlamentu Europejskiego i Rady 2002/91/WE z dnia 16 grudnia $2002 \mathrm{r}$. w sprawie charakterystyki energetycznej budynków.

Dyrektywa Parlamentu Europejskiego i Rady 2009/28/WE z dnia 23 kwietnia 2009 r. w sprawie promowania stosowania energii ze źródeł odnawialnych zmieniająca i w następstwie uchylająca dyrektywy 2001/77/WE oraz 2003/30/WE.

Dyrektywa Parlamentu Europejskiego i Rady 2009/125/WE z dnia 21 października 2009 r. ustanawiająca ogólne zasady ustalania wymogów dotyczących ekoprojektu dla produktów związanych $\mathrm{z}$ energią.

Dyrektywa Parlamentu Europejskiego i Rady 2010/31/ UE z dnia 19 maja $2010 \mathrm{r}$. w sprawie charakterystyki energetycznej budynków.

Dyrektywa Parlamentu Europejskiego i Rady 2012/27/UE z dnia 25 października 2012 r. w sprawie efektywności energetycznej, zmiany dyrektyw 2009/125/WE i 2010/30/UE oraz uchylenia dyrektyw 2004/8/WE i 2006/32/WE Tekst mający znaczenie dla EOG.

Hoffman A.J., Henn R., 2008, Overcoming the social and psychological barriers to green building, Organization and Environment, 21, 4, 390-419.

Hwang,B.G., Ng W.J., 2013, Project management knowledge and skills for green construction: Overcoming challenges, International Journal of Project Management, 31, 2, 272-284.

John G., Clements-Croome D., Jeronimidis G., 2005, Sustainable building solutions: a review of lessons from the natural world, Building and Environment, 40, 3, 319-328.

Kłos L., 2015, Świadomość ekologiczna Polaków przeglad badań, Studia i Prace Wydziału Nauk Ekonomicznych i Zarządzania, 42, 35-44.

Komisja Europejska, 2019a. Realizacja planu dziatania na rzecz gospodarki o obiegu zamkniętym. Ostateczny pakiet dotyczacy gospodarki o obiegu zamkniętym, https://ec.europa.eu/environment/ circular-economy, dostęp 22.09.2019.

Komurlu R., Arditi D., Gurgun A.P., 2015, Energy and atmosphere standards for sustainable design and construction in different countries, Energy and Buildings, 90, 156-165.

Lent T., Walsh B., 2008, Rethinking green building standards for comprehensive continuous improvement, Journal of ASTM International, 5, 2, 1-10.

Lewandowska A., 2015, Ekoinnowacje w zrównoważonym budownictwie - wprowadzenie do zagadnienia, Edukacja Biologiczna i Środowiska, 4, 34-40.

Lewandowska A., Rogatka K., 2017, Zielona architektura terenów zurbanizowanych $w$ świetle koncepcji ekologizacji miasta, Kwartalnik Architektury i Urbanistyki, 2, 61-72.

Mazur-Wierzbicka E., 2014, Ekoinnowacje - istotny element zrównoważonego budownictwa, Handel Wewnętrzny, 5, 352, 138-148. 
Nelson A.J., Rakau O., Dörrenberg P., 2010, Green buildings: a niche becomes mainstream, Deutsche Bank Research, 3-22.

Wu P., Low S.P., 2010, Project management and green buildings: lessons from the rating systems, Journal of Professional Issues in Engineering Education and Practice, 136, 2, 61-70.

Rozporządzenie Parlamentu Europejskiego i Rady (UE) nr 305/2011 z dnia 9 marca 2011 r. ustanawiające zharmonizowane warunki wprowadzania do obrotu wyrobów budowlanych i uchylające dyrektywę Rady 89/106/EWG.

Rozporządzenie Parlamentu Europejskiego i Rady (UE) 2017/1369 z dnia 4 lipca 2017 r. ustanawiające ramy etykietowania energetycznego i uchylające dyrektywę 2010/30/UE.

Szymańska D., Lewandowska A., Rogatka K., 2015, Temporal trend of green areas in Poland between 2004 and 2012, Urban Forestry and Urban Greening, 14, 4, 1009-1016.

USGBC, 2019, https://new.usgbc.org/, dostęp 27.01.2019.

Ulubeyli S., Kazanci O., 2018, Holistic sustainability assessment of green building industry in Turkey, Journal of Cleaner Production, 202, 197-212.

Todd J.A., Boecker J., 2008, Continuous improvement of the U.S. Green Building Council's leadership in energy and environmental design (LEED) rating system, Journal of ASTM International, 5 (1).

Trinius W., Sjoström C., 2007, Sustainability in Building construction-international standards in progress, Journal of ASTM International, 4 (7).
Wei W., Ramalho O., Mandin C., 2015, Indoor air quality requirements in green building certifications, Building and Environment, 92, 10-19.

Wilson A., 2006, Your Green Home: A Guide to Planning a Healthy, Environmentally Friendly New Home, New Society Publishers.

Xia B., Zuo J., Skitmore M., Pullen S., Chen Q., 2013, Review of green star points obtained by Australian building projects, Journal of Architectural Engineering, 19, 4, 302-8.

(Web-o1) BREEAM, 2019, https://www.breeam.com, dostęp 10.01.2019.

(Web-o2) DGNB, 2019, https://www.dgnb.de/en/ index.php, dostęp 10.01.2019.

(Web-o3) Główny Urząd Statystyczny (GUS), 2019, Dynamika produkcji przemystowej i budowlano - montażowej w grudniu 2018 r., http://stat.gov.pl/obszary-tematyczne/przemysl-budownictwo-srodki-trwale/przemysl/ dynamika-produkcji-przemyslowej-i-budowlano-montazowej-w-grudniu-2018-roku,5,83.html, dostęp (11.01.2019).

(Web-04) IWBI, 2019, https://www.wellcertified. com/en, dostęp 20.01.2019.

(Web-05) Komisja Europejska, 2019, W kierunku zrównoważonej Europy do 2030 roku, Bruksela, https://eur-lex.europa.eu/legal-content/EN/TXT/ HTML/?uri=CELEX:52019DCoo22\&from=EN, dostęp 20.09.2019.

(Web-06) Paradysz Ł., 2012, Zwróć uwagę na zielone budownictwo, https://www.bureauveritas.pl/ home/news/latest-news.

\title{
Some aspects of green building in Poland in the context of systems for certification of ecological buildings
}

\begin{abstract}
The goal of the paper is to explain special character and evaluate green building in Poland in the context of ecological building application process. The author tries to define social and economic factors contributing to development of this type of building in Poland. The paper also describes spatial variety in voivodeship scale in reference to localization of buildings with ecological certificate and points out green building structure in Poland. To complete the task, the author uses mainly the data from Polish Green Building Council. The work clearly indicates raise in number of certificates of ecological building, what evidences development of this type of building. We also observe spatial variety of green building in the country scale (most of these buildings are located in big cities of Poland).
\end{abstract}

\section{Keywords}

green building, ecological building, ecologisation, city, Poland 